\title{
PENGARUH KUALITAS LAYANAN, KUALITAS PRODUK, DAN HARGA TERHADAP KEPUASAN NASABAH KREDIT SERBA BISA PADA PD. BPR BKK KOTA SEMARANG PERIODE JUNI 2019
}

\author{
Ika Puspita Ardani*) \\ Jati Handayani**) \\ *) ikapuspitaar@gmail.com
}

\begin{abstract}
This purpose of this research is to analyze the effect of service quality, product quality, and price on customer satisfaction of Credit Serba Bisa at PD. BPR BKK Kota Semarang Period June 2019. This research is a causal applied quantitative research. The types of data used in this study are primary and secondary. Methods of data collection using questionnaires, interviews, and observation. The sampling technique used was purposive sampling technique with a sample of 100 respondents. Data testing methods used in this study are validity test, reliability test, normality test, multicollinearity test, heteroscedasticity test, autocorrelation test, multiple linear regression test, $F$ test, $t$ test, test the coefficient of determination $R^{2}$ which shows can be used to measure customer satisfaction. The analytical method used in this study is multiple linear regression using SPSS 25. The results of the F test show that the quality of service, product quality, and price simultaneously have a significant effect on customer satisfaction on Credit Serba Bisa in PD. BPR BKK Kota Semarang. Furthermore, the t test results showed that service quality, product quality, and price partially had a significant effect on customer satisfaction of Credit Serba Bisa at PD. BPR BKK Kota Semarang.
\end{abstract}

Keywords: Customer Satisfaction, Service Quality, Product Quality, and Price.

*) Mahasiswa Tugas Akhir Prodi Keuangan dan Perbankan Jurusan Akuntansi Politeknik Negeri Semarang

**) Dosen Jurusan Akuntansi Politeknik Negeri Semarang

\section{PENDAHULUAN}

\section{Latar Belakang Masalah}

Dewasa ini, lembaga keuangan mikro semakin berkembang di Indonesia, sehingga persaingan antar bank menjadi semakin ketat, khususnya persaingan dalam jasa layanan. setiap lembaga keuangan mikro, berusaha untuk menarik nasabah sebanyak-banyaknya dengan meningkatkan kualitas baik dari segi pelayanan, produk, bunga, tata cara prosedur, serta fasilitas yang ada (Subarjo, 2012). Salah satu cara yang harus ditempuh perusahaan dalam hal ini adalah dengan menentukan strategi yang tepat supaya tetap bertahan hidup di tengah persaingan serta dapat meningkatkan profitabilitasnya (Lumempow, dkk, 2015).

Kepuasan merupakan tingkat perasaan di mana seseorang menyatakan hasil perbandingan atas kinerja produk (jasa) yang diterima dan yang diharapkan (Lupiyoadi, 2013:228). Seluruh lembaga keuangan, tak terkecuali untuk perbankan termasuk BPR sangat bergantung pada kepercayaan masyarakat yang diperoleh dari kepuasan nasabah. Faktor-faktor yang memengaruhi kepuasan nasabah diantaranya adalah kualitas pelayanan (Hidayat, 2009; 
Yulinda, 2013; Novia dan Sutrisna, 2017; Rafica 2016), kualitas produk (Hidayat, 2009; Markoni, 2011; Suputra dan Mandala, 2014; Suwarni dan Mayasari, 2014), dan harga yang ditawarkan (Worodiyanti dan Maspiyah, 2016; Bilgies, 2016; Prasetio, 2012; Saputra, 2015). Untuk mencapai kepuasan tersebut, bank dituntut untuk dapat memberikan pelayanan yang terbaik.

Di bawah ini adalah tabel rating bank berkinerja terbaik tahun 2018 berdasarkan rating yang dilakukan oleh Biro Riset Infobank pada 115 bank se-Indonesia. Hasil rating dapat dilihat pada Tabel 1:

Tabel 1 Rating Bank Berkinerja Terbaik Tahun 2018

\begin{tabular}{|c|l|c|}
\hline Peringkat & \multicolumn{1}{|c|}{ Nama Bank } & Skor \\
\hline 1 & Bank Suryajaya Kubutambahan, Buleleng & $100 \%$ \\
\hline 2 & BPR Parasahabat Bekasi, Karawang & $99,80 \%$ \\
\hline 3 & BPR Bank Kota Bogor, Kota Bogor & $98,75 \%$ \\
\hline 4 & BPR Mekar Nugraha Klepu, Semarang & $98,63 \%$ \\
\hline 5 & BPR Cipatujah Jabar, Tasikmalaya & $98,28 \%$ \\
\hline 6 & BPR Kredit Mandiri Indonesia, Bekasi & $97,58 \%$ \\
\hline 7 & BPR Nusamba Cepiring, Kendal & $97,49 \%$ \\
\hline 8 & BPR Bank Magelang, Kota Magelang & $97,29 \%$ \\
\hline 9 & BPR Gunung Simping Artha, Banyumas & $97,22 \%$ \\
\hline 10 & BPR BKK Tasikmadu, Karanganyar & $97,17 \%$ \\
\hline
\end{tabular}

Sumber: Data Sekunder majalah Infobank No. 480. Juli 2018. Vol. XL.

Berdasarkan data hasil rating BPR berkinerja terbaik di atas, dapat diketahui bahwa PD. BPR BKK Kota Semarang belum masuk pada rating 10 BPR berkinerja terbaik. Hal ini menjadi penanda bahwa PD. BPR BKK Kota Semarang masih harus mengadakan evaluasi dan memperbaiki kinerjanya. Perbaikan tersebut dapat dilakukan dengan cara meningkatkan kepuasan nasabah. Selain dari belum termasuknya PD. BPR BKK Kota Semarang dalam rating 10 besar BPR berkinerja terbaik se-Indonesia, untuk mengetahui sebaik apakah kinerja PD. BPR BKK Kota Semarang maka dilakukan pra survey, hasil dari pra survey tersebut menunjukkan bahwa masih terdapat beberapa kekurangan, diantaranya nasabah merasa kecewa karena bank tidak memenuhi janjinya untuk memroses kredit selama beberapa waktu sesuai dengan yang sudah dijanjikan, dan terdapat pula nasabah yang mengeluhkan bahwa potongan untuk biaya administrasi terlalu tinggi, sehingga jumlah pinjaman yang diharapkan diterima menjadi berkurang banyak. 


\section{Rumusan Masalah}

Berdasarkan latar belakang di atas, Tugas Akhir ini dibuat untuk mengkaji lebih lanjut mengenai tingkat kepuasan nasabah Kredit Serba Bisa pada PD. BPR BKK Kota Semarang. Oleh sebab itu, penulis mengambil judul "Pengaruh Kualitas Layanan, Kualitas Produk, dan Harga Terhadap Kepuasan Nasabah Kredit Serba Bisa Pada PD. BPR BKK Kota Semarang Periode Juni 2019".

\section{KAJIAN TEORI \\ Pengertian Bank}

Menurut Undang-Undang No.10 tahun 1998 tentang Perbankan, bank adalah badan usaha yang menghimpun dana dari masyarakat dalam bentuk simpanan dan menyalurkannya kembali pada masyarakat dalam bentuk kredit dan atau bentuk lainnya dalam rangka meningkatkan taraf hidup rakyat banyak.

Menurut Kasmir (2012:2), secara sederhana bank dapat diartikan sebagai lembaga keuangan yang kegiatan utamanya adalah menghimpun dana dari masyarakat dan menyalurkan kembali dana tersebut ke masyarakat serta memberikan jasa bank lainnya.

\section{Pengertian Kredit}

Dalam bahasa latin kredit disebut "credere", yang artinya "percaya". Maksudnya si pemberi kredit percaya kepada si penerima kredit, bahwa kredit yang disalurkan pasti akan dikembalikan sesuai perjanjian. Sedangkan bagi si penerima kredit berarti mendapat kepercayaan, sehingga mempunyai kewajiban untuk membayar kembali pinjaman tersebut sesuai dengan jangka waktunya (Kasmir, 2002:101).

Sedangkan pengertian kredit menurut Undang-Undang Perbankan Nomor 10 tahun 1998 adalah penyediaan uang atau tagihan yang dapat dipersamakan dengan itu, berdasarkan persetujuan atau kesepakatan pinjam meminjam antara bank dengan pihak peminjam melunasi utangnya setelah jangka waktu tertentu dengan pemberian bunga (Kasmir, 2002:102).

\section{Kepuasan Nasabah}

Kepuasan merupakan tingkat perasaan dimana seseorang menyatakan hasil perbandingan atas kinerja produk (jasa) yang diterima dan yang diharapkan (Lupiyoadi, 2013:228). Menurut Howard dan Shets dalam Tjiptono 2009, kepuasan pelanggan adalah situasi kognitif pembeli berkenaan dengan kesepadanan atau ketidaksepadanan antara hasil yang didapat dibandingkan dengan pengorbanan yang dilakukan (Yulinda, 2013). 


\section{Kualitas Layanan}

Menurut American Society for Quality Control dalam Ratnasari dan Aksa (2011:103) kualitas adalah keseluruhan dari ciri-ciri dan karakteristik-karakteristik dari suatu produk/jasa dalam hal kemampuannya untuk memenuhi kebutuhan-kebutuhan yang telah ditentukan atau bersifat laten, dan dengan kata lain kualitas suatu produk/jasa adalah sejauh mana produk/jasa memenuhi spesifikasi-spesifikasinya.

Kualitas layanan merupakan totalitas dari bentuk karakteristik barang dan jasa yang menunjukkan kemampuannya untuk memuaskan kebutuhan pelanggan, baik yang nampak jelas maupun yang tersembunyi. Bagi perusahaan yang bergerak di sektor jasa, pemberian pelayanan yang berkualitas pada pelanggan merupakan hal mutlak yang harus dilakukan apabila perusahaan ingin mencapai keberhasilan (Kotler, 2000:25).

\section{Kualitas produk}

Kotler (1996:274) menyatakan produk adalah segala sesuatu yang ditawarkan ke pasar untuk mendapatkan perhatian, dibeli, dipergunakan atau dikonsumsi yang dapat memuaskan keinginan atau kebutuhan konsumen.

Menurut Payne (1993) (dalam Hidayat, 2009) kualitas produk adalah suatu bentuk dengan nilai kepuasan yang kompleks. Berdasarkan pendapat Payne tersebut, Hidayat (2009) menyimpulkan bahwa kualitas produk perbankan didapatkan dengan cara menemukan keseluruhan harapan nasabah, meningkatkan nilai produk atau pelayanan dalam rangka memenuhi harapan nasabah tersebut.

\section{Harga}

Menurut Kotler dan Amstrong (dalam Bilgies 2016), harga adalah sejumlah uang yang dibebankan atas suatu produk atau jasa, atau jumlah dari nilai yang ditukar pelanggan atas manfaat-manfaat karena memiliki atau menggunakan produk atau jasa tersebut.

Harga menurut Kotler (2008:345) adalah jumlah semua nilai yang diberikan oleh pelanggan untuk mendapatkan keuntungan dari memiliki atau menggunakan suatu produk atau jasa.

Sedangkan menurut Tjiptono (2001) harga sering kali digunakan sebagai indikator nilai bagaimana harga tersebut dihubungkan dengan manfaat yang dirasakan atas suatu barang atau jasa. Dengan demikian dapat disimpulkan bahwa pada tingkat harga tertentu, bila manfaat yang dirasakan konsumen meningkat maka nilainya akan meningkat pula. 


\section{Kerangka Pemikiran Teoritis}

Berdasarkan uraian teoritis di atas dibangun suatu model kerangka pikir teoritis penelitian sebagai berikut:

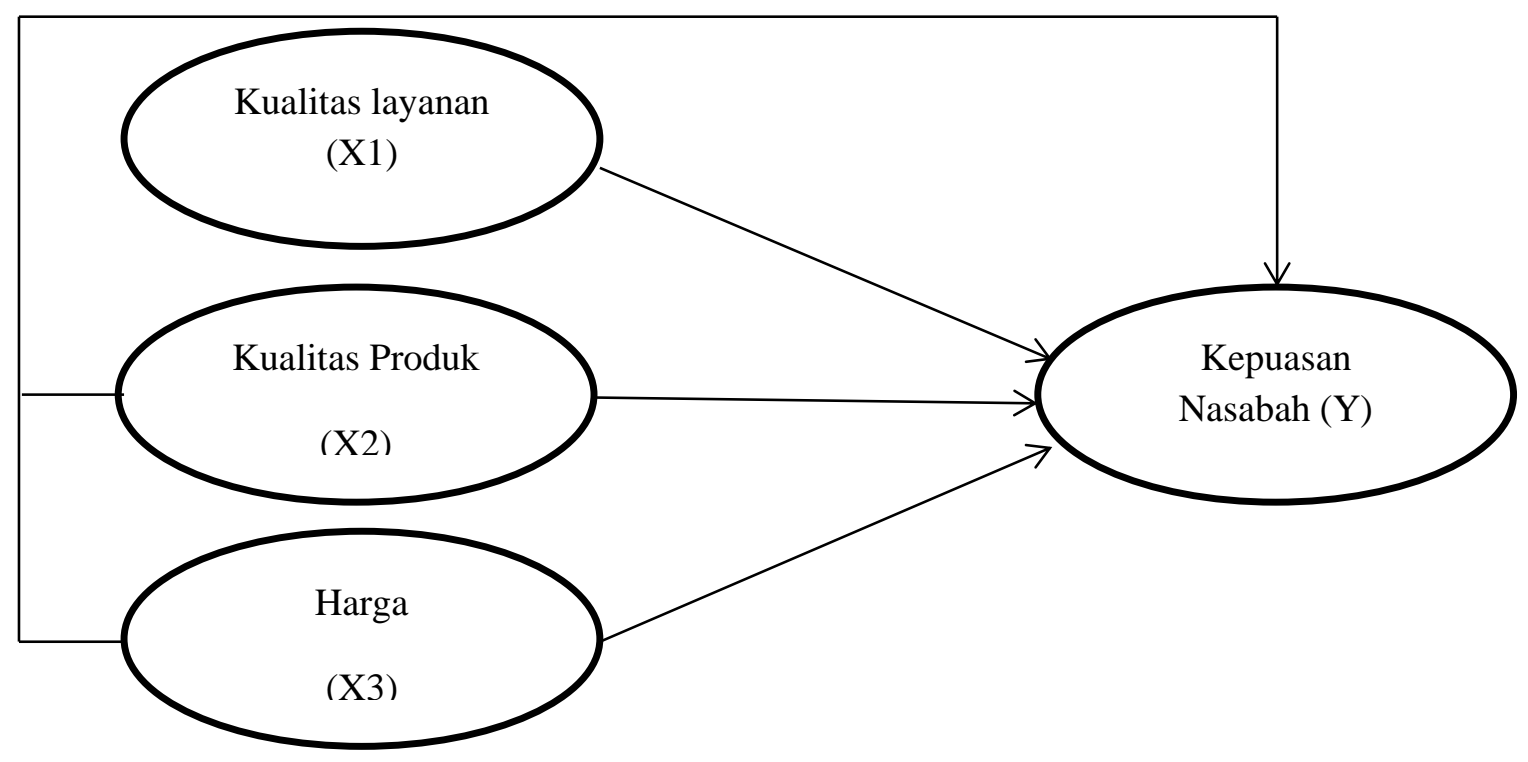

Gambar 1 Kerangka Pikir Teoritis

(Sumber: Hidayat (2009), Umar (2002), Saputra (2015) dikembangkan untuk Tugas Akhir)

\section{METODE}

\section{Desain Penelitian}

Desain penelitian yang digunakan dalam penelitian ini adalah penelitian terapan kausal. Penelitian jenis kausal berguna untuk mengukur hubungan-hubungan antara variabel riset, atau berguna untuk menganalisis bagaimana suatu variabel mempengaruhi variabel lain (Umar, 2003:40).

\section{Populasi dan Sampel}

Populasi dalam penelitian ini yaitu seluruh nasabah Kredit Serba Bisa PD. BPR BKK Kota Semarang. Jumlah sampel sebanyak 100 responden. Teknik pengambilan sampel menggunakan purposive sampling.

Instrumen penelitian dalam penelitian ini menggunakan kuesioner dengan pertanyaan terbuka dan pertanyaan tertutup menggunakan skala likert mulai dari Sangat Tidak Setuju (STS), Tidak Setuju (TS), Setuju (S), dan Sangat Setuju (SS). Teknik analisis dengan menggunakan bantuan program software SPSS 25 yang terdiri dari Uji Instrumen Penelitian (Uji Validitas dan Uji Reliabilitas), Uji Asumsi Klasik (Uji Normalitas, Uji Multikolonieritas, 
Uji Heteroskedastisitas, dan Uji Autokorelasi), dan Uji Regresi Linear Berganda (Uji F, Uji R, dan Uji t).

\section{HASIL DAN PEMBAHASAN}

\section{Uji Validitas dan Reliabilitas}

Hasil uji validitas menunjukkan bahwa $r_{h i t u n g}$ dari semua indikator lebih besar dari $r_{\text {tabel}}$. Sehingga seluruh pertanyaan dalam kuesioner ini dinyatakan valid. Hasil uji reliabilitas menunjukkan bahwa nilai cronbach's alpha dari semua variabel lebih besar dari 0,7 memenuhi kriteria yang telah ditetapkan sehingga data tersebut dinyatakan reliabilitas.

\section{Uji Asumsi Klasik}

\section{Uji Normalitas}

Dari uji normalitas menghasilkan nilai asymptotic significance sebesar 0,200 lebih besar dari 0,05 atau 5\%, sehingga variabel pengganggu atau residual memiliki distribusi normal. Dengan demikian model regresi layak digunakan untuk melakukan penelitian.

\section{Uji Multikolonieritas}

Hasil perhitungan uji multikolonieritas menunjukkan bahwa semua variabel memiliki nilai Tolerance $\geq 0,10$ dan nilai $\mathrm{VIF} \leq 10$. Hal ini menunjukkan tidak ada multikolinieritas antar variabel independen dalam model regresi.

\section{Uji Heteroskedastisitas}

Berdasarkan uji heteroskedastisitas dengan jelas menunjukkan bahwa tidak ada satupun variabel independen yang signifikan secara statistik mempengaruhi variabel dependen nilai Absolut Res (ABS_RES). Hal ini terlihat dari probabilitas signifikansi diatas 5\% atau 0,05. Jadi dapat disimpulkan model regresi tidak terdapat heteroskedastisitas.

\section{Uji Autokorelasi}

Berdasarkan uji autokorelasi diperoleh persamaan: 1,7364 (du) $<2,008$ (DW) $<2,2636$ (4-du). Dari persamaan tersebut maka dapat disimpulkan bahwa tidak ada autokorelasi positif dan negatif, artinya tidak terdapat autokeralasi pada model regresi ini.

\section{Hasil Uji Regresi}

\section{Uji Koefisien Determinasi $\left(\mathbf{R}^{2}\right)$}

Besarnya nilai koefisien determinasi (Adjusted $R^{2}$ ) dalam penelitian ini sebesar 0,565. Artinya variabel kualitas layanan, kualitas produk, dan harga memberikan kontribusi pengaruh terhadap keputusan nasabah menabung sebesar 56,5 \%. Sedangkan sisanya sebesar 43,5 \% dipengaruhi oleh variabel lain yang tidak diteliti dalam penelitian ini. 


\section{Hasil Uji F (Simultan)}

Hasil uji F menunjukkan bahwa secara bersama-sama kualitas layanan, kualitas produk, dan harga secara simultan berpengaruh signifikan terhadap kepuasan nasabah Kredit Serba Bisa pada PD. BPR BKK Kota Semarang. Hal ini terlihat dari hasil uji F menunjukkan bahwa $F_{\text {hitung }}=43,927>F_{\text {tabel }}=2,70$ atau signifikansi $=0,000<0,05$.

\section{Uji t (Parsial)}

Berdasarkan hasil pengujian uji t, diperoleh nilai thitung dari tiga variabel independen yaitu variabel harga dengan nilai thitung 6,268 lebih besar dari tabel 1,98472, variabel kualitas layanan dengan thitung 3,643 lebih besar dari $t_{\text {tabel }}$ 1,98472 dan variabel produk dengan $t_{\text {hitung }}$ 2,094 lebih besar dari $t_{\text {tabel }}$ 1,98472. Hal ini menunjukkan bahwa hipotesis 2, hipotesis 3 dan hipotesis 4 dinyatakan diterima.

\section{PENUTUP}

\section{Kesimpulan}

Kesimpulan penelitian ini adalah hasil uji F menunjukkan bahwa kualitas layanan, kualitas produk, dan harga secara simultan berpengaruh signifikan terhadap kepuasan nasabah Kredit Serba Bisa pada PD. BPR BKK Kota Semarang. Selanjutnya hasil uji t menunjukkan bahwa kualitas layanan, kualitas produk, dan harga secara parsial berpengaruh signifikan terhadap kepuasan nasabah Kredit Serba Bisa pada PD. BPR BKK Kota Semarang. Hal tersebut didasarkan pendahuluan sebagai berikut:

1. Variabel kualitas layanan, kualitas produk, dan harga secara simultan berpengaruh signifikan terhadap kepuasan nasabah Kredit Serba Bisa pada PD. BPR BKK Kota Semarang Periode Juni 2019.

2. Variabel kualitas layanan secara parsial berpengaruh signifikan terhadap kepuasan nasabah Kredit Serba Bisa pada PD. BPR BKK Kota Semarang Periode Juni 2019.

3. Variabel kualitas produk secara parsial berpengaruh signifikan terhadap kepuasan nasabah Kredit Serba Bisa pada PD. BPR BKK Kota Semarang Periode Juni 2019.

4. Variabel harga secara parsial berpengaruh signifikan terhadap kepuasan nasabah Kredit Serba Bisa pada PD. BPR BKK Kota Semarang Periode Juni 2019.

\section{Implikasi}

Implikasi teoritis merupakan hasil dari setiap peneliti, dimana implikasi teoritis menggambarkan perbandingan tentang referensi yang digunakan dalam penelitian ini, mengacu dari penelitian sebelumnya dan temuan penelitian. Implikasi teori yang dikembangkan dalam penelitian ini bertujuan untuk penguatan dukungan pada beberapa 
penelitian sebelumnya sebagai referensi kualitas layanan, kualitas produk, dan harga terhadap kepuasan nasabah. Beberapa hasil penelitian sebelumnya seperti ditampilkan di Tabel 2 berikut ini:

Tabel 2 Implikasi Teoritis

\begin{tabular}{|c|l|l|}
\hline No & \multicolumn{1}{|c|}{ Hasil Penelitian Sekarang } & \multicolumn{1}{c|}{ Penelitian Terdahulu } \\
\hline 1 & $\begin{array}{l}\text { Kepuasan nasabah Kredit Serba } \\
\text { Bisa dapat dipengaruhi oleh } \\
\text { variabel kualitas layanan. }\end{array}$ & $\begin{array}{l}\text { Kepuasan nasabah Kredit Serba Bisa dapat } \\
\text { dipengaruhi oleh variabel kualitas layanan, } \\
\text { sejalan dengan penelitian yang dilakukan oleh } \\
\text { Novia dan Sutrisna (2017), Hidayat (2009), dan } \\
\text { Yulinda (2013). }\end{array}$ \\
\hline 2 & $\begin{array}{l}\text { Kepuasan nasabah Kredit Serba } \\
\text { Bisa dapat dipengaruhi oleh } \\
\text { variabel kualitas produk. }\end{array}$ & $\begin{array}{l}\text { Kepuasan nasabah Kredit Serba Bisa dapat } \\
\text { dipengaruhi oleh variabel kualitas produk, } \\
\text { sejalan dengan penelitian yang dilakukan oleh } \\
\text { Saputra dan Mandala (2014), Hidayat (2009), } \\
\text { serta Suwarni dan Mayasari (2014). }\end{array}$ \\
\hline 3 & $\begin{array}{l}\text { Kepuasan nasabah Kredit Serba } \\
\text { Bisa dapat dipengaruhi oleh } \\
\text { variabel harga. }\end{array}$ & $\begin{array}{l}\text { Kepuasan nasabah Kredit Serba Bisa dapat } \\
\text { dipengaruhi oleh variabel kualitas layanan, } \\
\text { sejalan dengan penelitian yang dilakukan oleh } \\
\text { Prasetio (2012), Bilgies (2016), dan Saputra } \\
\text { (2015) }\end{array}$ \\
\hline
\end{tabular}

\section{Implikasi Manajerial}

Hasil pembahasan yang telah dijelaskan sebelumnya, maka didapatkan tambahan referensi dan informasi bagi perbankan guna meningkatkan kepuasan nasabah kredit, maka beberapa implikasi manajerial yang dapat diberikan adalah sebagai berikut:

1. Harga merupakan variabel yang paling tinggi pengaruhnya terhadap kepuasan nasabah kredit. Hal ini berarti, nasabah kredit telah merasakan kepuasan terhadap harga yang ditawarkan oleh bank. Maka, pihak bank diharapkan mempertahankan strategi penetapan harga yang telah diterapkan, yaitu dengan memberikan harga yang terjangkau dan sesuai dengan kualitas produk yang yang ditawarkan.

2. Kualitas layanan merupakan variabel kedua yang berpengaruh terhadap kepuasan nasabah kredit. Oleh karena itu, pihak bank diharapkan mempertahankan dan meningkatkan kualitas layanan. Hal tersebut dapat dilakukan melalui peningkatan pelayanan teller dan customer service baik saat nasabah ingin membuka atau mengajukan aplikasi kredit dan saat nasabah kredit ingin melakukan pemmbayaran angsuran.

3. Kualitas produk merupakan variabel yang paling rendah pengaruhnya terhadap kepuasan nasabah kredit. Sehingga diharapkan bank mampu meningkatkan kualitas produknya demi kepuasan pengguna produk bank secara umum dan khususnya produk Kredit Serba Bisa. 


\section{Keterbatasan Penelitian}

Keterbatasan dalam penelitian ini adalah sebagai berikut:

1. Variabel yang diteliti dalam penelitian ini hanya sebatas kualitas layanan, kualitas produk, dan harga saja.

2. Objek pada penelitian ini terbatas hanya pada PD. BPR BKK Kota Semarang dengan kriteria sampel tertentu.

\section{DAFTAR PUSTAKA}

Bilgies. 2016. "Peran Kualitas Produk, harga, dan Kualitas Layanan Terhadap Kepuasan Pelanggan Billagio Scincare Clinic Sidoarjo". Jurnal EkoNiKa. Volume 1, Nomor 1, April.

Duriany, Embun Soemarso. 2011. Etika Pelayanan Jasa Keuangan. Semarang: Polines.

Ferdinand, Augusty. 2006. Metode Penelitian Manajemen. Semarang: SeriPustaka Kunci.

Ghozali, Imam. 2018. Aplikasi Analisis Multivariate dengan Program IBM SPSS 25 Edisi 9. Semarang: Badan Penerbit Undip.

Hidayat, Rachmad. 2009. Pengaruh Kualitas Layanan, Kualitas Produk, dan Nilai Nasabah Terhadap Kepuasan dan Loyalitas Nasabah bank mandiri. Jurnal Manajemen dan Kewirausahaan. Vol. 11, No. 1, Maret.

Infobank. 2018. Bank Berkinerja Terbaik, Jakarta: Infobank. Juli.

Kasmir. 2002. Dasar-Dasar Perbankan. Jakarta: PT Raja Grafindo.

Kotler dan Keller. 2008. Manajemen Pemasaran Jilid 2. Jakarta: Indeks.

Lumempow, dkk. 2015. "Analisis Faktor-faktor Kualitas Pelayanan Terhadap Kepuasan

Nasabah Pada PT. Bank Mandiri Tbk Cabang Bahu Mall Manado”. Jurnal EMBA. Volume 3, Nomor 3, September.

Lupiyoadi, Rambat dan A. Hamdani. 2009. Manajemen Pemasaran Jasa. Jakarta: Salemba Empat.

Lupiyoadi, Rambat. 2013. Manajemen Pemasaran Jasa. Jakarta: Salemba Empat.

Markoni. 2011. "Pengaruh Dimensi Kualitas Produk Terhadap Kepuasan Nasabah Perbankan”. Jurnal Ilmiah Orasi Bisnis. Edisi ke-IV, November.

Nazir, Moh. 2013. Metode Penelitian. Bogor: Ghalia Indonesia.

Novia dan Sutrisna. 2017. "Pengaruh Kualitas Pelayanan dan Harga Terhadap Kepuasan Pelanggan Pada Expedisi di Pekanbaru (Studi PT. JNE (Jalur Nugraha Ekakurir) Pekanbaru)". Jom FISIP. Volume 4, Nomor 2, Oktober. 
Prasetio. 2012. "Pengaruh Kualitas Layanan dan Harga Terhadap Kepuasan Pelanggan”. Management Analysis Journal 1 (4).

Rafica. 2016. “Analisis Faktor-faktor Yang Mempengaruhi Kepuasan Nasabah Pada PT. Bank Rakyat Indonesia Kanca Ponorogo”. Jurnal JIBEKA. Volume 10, Nomor 1, Agustus.

Ratnasari dan Aksa. 2011. Manajemen Pemasaran Jasa. Bogor: Ghalia Indonesia.

Riyadi. 2012. Pemasaran Jasa. Semarang: MediAN Polines.

Saputra, Angga Mardian. 2015. "Peran Kualitas Layanan, Kualitas Produk, dan Harga Terhadap Kepuasan Nasabah Kredit Usaha Rakyat Mikro (Studi Kasus PT. Bank Rakyat Indonesia (Persero), Tbk Kantor Cabang Kudus)". Tugas Akhir. Semarang: Jurusan Akuntansi Polines.

Sarjono, Haryadi dan Winda Julianita. 2011. SPSS vs LISREL Sebuah Pengantar, Aplikasi untuk Riset. Jakarta: Salemba Empat.

Sarwono, Jonathan. 2006. Metode Penelitian Kuantitatif dan Kualitatif. Yogyakarta: Graha Ilmu.

Simamora, Bilson. 2004. Riset Pemasaran. Jakarta: PT Gramedia Pustaka Utama.

Subarjo, 2012. "Pengaruh Kepuasan Terhadap Loyalitas Nasabah Kredit Pada BUKP Nanggulan”. Jurnal Sosihumaniora. Volume 3, Nomor 3, Yogyakarta.

Sugiyono. 2007. Metode Penelitian Kuantitatif, Kualitatif dan $R \&$ D. Bandung: CV Alfabeta. Sugiyono. 2015. Metode Penelitian Kuantitatif, Kualitatif dan $R \& D$. Bandung: Alfabeta.

Supranto, J. 2006. Pengukuran Tingkat Kepuasan Pelanggan Untuk Menaikkan Pangsa Pasar. Jakarta: Rineka Cipta.

Suputra dan Mandala. 2014. "Pengaruh Kualitas Pelayanan dan Kualitas Produk Kredit Multiguna Terhadap Kepuasan Nasabah Kredit Multiguna Terhadap Kepuasan Nasabah Kredit Pada PT. BPR HOKI Cabang Denpasar”. Jurnal Ekonomi dan Bisnis. Bali.

Suwarni dan Mayasari. 2011. "Pengaruh Kualitas Produk dan Harga Terhadap Loyalitas Melalui Kepuasan Konsumen”. Jurnal Ekonomi Bisnis. Nomor 1, Maret.

Tika, Moh. Pabundu. 2006. Metodologi Riset Bisnis. Jakarta: PT Bumi Aksara. Umar, Husein. 2003. Metode Riset Perilaku Konsumen Jasa. Jakarta: Ghalia Indonesia.

Usman, Husaini dan Purnomo S. Akbar. 2003. Metodologi Penelitian Sosial. Jakarta: Bumi Aksara.

Wahjono, Sentot Imam. 2010. Manajemen Pemasaran Bank. Yogyakarta: Graha Ilmu. Worodiyanti dan Maspiyah. 2016. "Pengaruh Kualitas Produk, Harga, dan Kualitas Layanan Terhadap Kepuasan Konsumen di Elladerma Skin Care Malang”. E-Journal. Volume 5, Nomor 1, Juli. 
keunis Majalah IImiah - ISSN No 2302-9315 Vol. 8 No 1 Thn VIII Januari 2020

Yulinda. 2013. “Analisis Pengaruh Kualitas Pelayanan Terhadap Kepuasan Nasabah Kredit Sumut Sejahtera I Pada PT Bank Sumut Cabang Utama Medan”. Jurnal Ekonom. Volume 16, Nomor 1, Sumatera Utara.

http://bkkkotasemarang.co.id/ 